\title{
Helsetransport med svikt
}

\author{
Natt til 1.9. 2013 ble min kone innlagt med akutt hjerteinfarkt ved sykehuset på Gjøvik. Neste dag ble hun over- \\ flyttet til Ullevål. Behandlingen ved begge sykehus var utmerket, men tilbakeføringen til Gjøvik ble annerledes.
}

Før legevisitten på Oslo universitetssykehus, Ullevål 3.9.fikk vi vite at hun ville få helsebusstransport tilbake til Gjøvik. Men bussavgangen var først kl 14. Dermed ville hun først komme dit ut på ettermiddagen. Under legevisitten ca. kl 1015 foreslo jeg derfor at hun kunne få kjøre med meg. Mitt forslag ble avvist, dels fordi det var i strid med rutinene, dels av sikkerhetsmessige årsaker. Jeg fikk høre at jeg neppe ville fungere både som sjåfør og hjelper hvis noe inntraff. I helsebussen ville dette bli tatt hånd om av medisinsk personell. Jeg bøyde meg for disse argumentene, ikke minst for å unngå konflikt.

Etter ca. $3 \frac{1}{1 / 2}$ times venting i korridoren fikk min kone gå ut til bussen. Under den vel $2 \frac{1}{2}$ times bussreisen via Eidsvoll og Hamar til Moelv fikk hun ingen spørsmål om hvordan hun hadde det. I Moelv var bussturen over, og hun ble kjørt til Gjøvik som eneste passasjer i en vanlig drosje.

\section{Lokalsykehuset}

Hun ankom mottakelsen på Sykehuset Innlandet Gjøvik ca. kl 17. Her var det nå kveldsbemanning og stor pågang av øyeblikkelig hjelp-pasienter. Jeg kom dit noen minutter senere etter å ha kjørt via vårt hjemsted i Hov i Land. Vennlige sykepleiere forsøkte å holde vårt humør oppe, mens tiden gikk. Etter $21 / 2$ time fikk jeg en kort samtale med vakthavende lege. Jeg forsikret meg om at epikrisepapirene fra Ullevål var kommet frem og jeg informerte om svaret på INR-prøven som var tatt på Ullevål samme morgen og som ikke var kommet med i epikrisen. Etter samtalen med vaktlegen følte jeg meg trygg på at ventetiden snart var over. Derfor valgte jeg å kjøre hjem før nattemørket satte inn. Men det gikk ikke som jeg trodde.

Først kl 2315 var hun på plass i et firesengsrom ved hjerteavdelingen. Det var nå gått ca. 68 timer siden symptomene startet. 13 av disse timene var gått med til overføringen tilbake fra sykepost ved Ullevål til sykepost ved Gjøvik, hvorav ca. ti timers venting og tre timers transport.

I mottakelsen hadde hun fått forsikring om at epikrisepapirene fra Ullevål ville følge henne opp på sykeposten og at hun ville bli hjerteovervåket natten igjennom. Dessverre ble papirene forsinket, og overvåkingen måtte sløyfes pga. for lite overvåkingsutstyr på posten.

For min kone hadde det for lengst gått på humøret og tilliten løs. Hun følte seg utrygg, glemt og nedprioritert, noe som lett går over i mindreverdighetsfølelse. Natten ble nesten søvnløs. Kl 0130 ble hun plutselig tildelt to tabletter. Hun oppfattet ikke hva tablettene gjaldt. Av frykt for feilmedisinering eller dobbeltdosering valgte hun å la tablettene bli på nattbordet. Under legevisitten samme formiddag fikk vi oppklart at det dreide seg om legemidler som skulle ha vært gitt mens hun lå i mottakelsen kvelden før.

På grunn av subfebrilia ble hun liggende et ekstra døgn på Gjøvik. Hun fikk nå mye vennlig oppmerksomhet, og postlegen beklaget den del av miseren som gjaldt Gjøvik. Dette ble også nevnt i epikrisen til fastlegen. 5.9. 2013 fikk jeg lov til å kjøre min kone til vårt hjem, en distanse på $28 \mathrm{~km}$ - gratis for Nav.

Denne historien må leses med bakgrunn $i$ at min kone har hatt flere akutte kardiovaskulære episoder forut for hjerteinfarktet.

Jeg har flere nære bekjente i Innlandet som har opplevd lange reiser og ventetider. Min tentative diagnose i dette tilfellet administrativ systemsvikt - synes oppstått i skjæringspunktet mellom Nav og hjerteavdelingene ved Ullevål og Gjøvik. Noen ansvarlige må ta tak i dette.

Kona har bidratt både til innhold og skriving og har gitt samtykke til at artikkelen blir publisert.

\section{Per Knut M. Lunde}

per.knut.m.lunde@gmail.com

Per Knut M. Lunde (f. 1934) er pensjonert lege, spesialist i klinisk farmakologi og klinisk kjemi og professor emeritus.

Mottatt 12.9.2013 og godkjent 26.9.2013. Redaktør: Erlend Hem.

\section{Kommentar}

\section{En forventet effekt}

Det er bra at Per Knut Lunde og hans ektefelle beretter om sine erfaringer. Antakelig er det mange som opplever liknede ting, men som ikke har krefter, ressurser eller mot til å fortelle offentlig om det. Vi må spørre: Skyldes det aktuelle tilfellet uflaks, slendrian eller sviktende vurderinger, eller skyldes det at noen har bestemt at det skal være sånn?

Helseplanleggere har i mange år lagt stor vekt på å redusere sengetall og liggetid.
Allerede for 11 år siden brukte daværende Helse Øst en SINTEF-utredning som viste at liggetiden var blitt redusert som argument for at ytterligere liggetidsreduksjon var ønskelig (1). Omtrent like lenge har vi hatt vitenskapelige holdepunkter for den nokså intuitive kunnskapen at for kort liggetid gir høyere risiko for reinnleggelser (2). Norge er nå blant de landene i Europa som har færrest sykehussenger per innbygger (3). I perioden 2005-12 skjedde det en reduksjon på $2000(16 \%)$ somatiske og $1000(20 \%)$ psykiatriske sykehussenger (4). I samme periode steg de samlede utgiftene til ambulansetjenesten med $39 \%$, mens utgiftene til spesialisthelsetjenesten samlet bare steg med $13 \%$ (regnet i faste priser) (4). Det kan altså se ut til at vi bruker stadig mer ressurser på å sende pasienter omkring, og relativt mindre på å behandle dem.

Likevel står lavere sengetall og kortere liggetid langt fremme i planleggernes 
bevissthet når det bygges nye sykehus - for tiden f.eks. i Østfold (5). Begrunnelsen er at senger er dyre. Men paradokset er at jo færre senger man har, desto dyrere fremstår hver seng. Dette skyldes dels at nevneren minker i den nokså primitive brøken sykehuskostnader dividert med sengetall (6).

Men det skyldes også at pasientarbeidet på en sengepost er mest omfattende i forbindelse med innleggelse og utskrivning. Derfor fører sengetallsreduksjoner sjelden til de innsparingene man forespeiler, men de fører til at sengene fremstår som enda dyrere og ytterligere reduksjoner som enda mer påkrevet. Det er på tide å tenke annerledes.

Det skumle med incentiver er at de virker. Når målet er kort liggetid og ingen økning i overbelegget tross redusert sengetall, ja så er leger tilpasningsdyktige og gjør som det blir forventet. Det betyr større innsats for å få tømt sengeposten fort (selv om transporten ikke er klar) og større belastning på mottaksapparatet i kommunene og $i$ andre sykehus. Prisen for denne intenderte utviklingen er ikke først og fremst økonomisk, men den må likevel betales av noen pasientene.

Torgeir Bruun Wyller

t.b.wyller@medisin.uio.no

Torgeir Bruun Wyller (f. 1960) er spesialist $\mathrm{i}$ indremedisin og geriatri, lege ved Geriatrisk avdeling. Oslo universitetssykehus og professor ved Det medisinske fakultet, Universitetet i Oslo.

Forfatter har fylt ut ICMJE-skjemaet og oppgir ingen interessekonflikter.

\section{Litteratur}

1. Wyller TB. Sengebehov og tallakrobatikk. Tidsskr Nor Lægeforen 2002; 122: 2591.

2. Heggestad T. Do hospital length of stay and staffing ratio affect elderly patients' risk of readmission? A nation-wide study of Norwegian hospitals. Health Serv Res 2002; 37: 647-65.

3. OECD. Health at a Glance 2011. www.oecd.org/ health/health-systems/49105858.pdf (20.10.2013).

4. Samdata. Spesialisthelsetjenesten 2012. Rapport IS-2074. Oslo: Helsedirektoratet, 2013. www.helsedirektoratet.no/publikasjoner/ samdata-2012/Sider/default.aspx (20.10.2013)

5. Ystrøm B. Østfolds nye sykehus tar form. Halden Arbeiderblad 9.10.2008. www.ha-halden.no/ nyheter/article4965 232.ece (15.10.2013).

6. Stien R. Skivepris - et fors $\varnothing k$ på å bedre økonomistyringen i norske sykehus. Tidsskr Nor Lægeforen 2001; 121: 1132. 